\title{
„Kultūros objektų katalogavimo" taikymo patirtis: kultūros paveldo bendruomenei skirta kodavimo metodika
}

\section{Erin COBURN}

J. Paul Getty muziejus, Los Andželas, JAV, el. p. ecoburn@getty.edu

Elisa LANZI

Smith kolegija, Northamptonas, JAV, el. p. elanzi@smith.edu

Elizabeth O'KEEFE

Morgan biblioteka ir muziejus, Niujorkas, JAV, el. p. eokeefe@themorgan.org

Regine STEIN

Fotovaizdu archyvas, Marburgas, Philipps universitetas, Marburgas, Vokietija, el. p. regine.stein@staff Ann WHITESIDE

Masačusetso technologijos institutas, Kembridžas, JAV, el. p. awhites@mit.edu

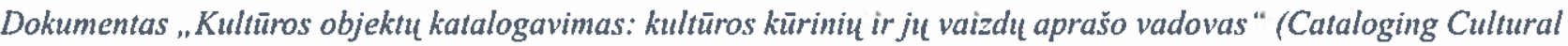
Objects: a Guide to Describing Cultural Works and Their Images - CCO) nuo pat jo paskelbimo $2003 \mathrm{~m}$. teike pagrindq turtingai katalogavimo praktikai formuotis. CCO yra kultüros kürinil ir ju vaizdo pakaitalı aprašo, dokumentavimo ir katalogavimo praktinis vadovas. CCO pagrindinis dèmesys skiriamas menui ir architektürai, taip pat tapybai, skulptürai, graviüroms, rankrašciams, nuotraukoms, statiniams, instaliacijoms ir kitokioms vaizdo priemonèms, taçiau jomis neapsiribojama. Jis taip pat taikytinas daugeliui kitı kultüros kürinil rüšĭ tarp ju ir archeologiniy kasinejjimu vietoms, artefaktams, materialiosios kultüros sričiai priklausantiems funkciniams objektams.

Siame straipsnyje nagrinejama CCO itaka ir jo taikymas katalogavimo ntostatoms, skirtoms muzieju ir vaizdt biblioteku bendruomenèms. Sujungdami tris skirtingus veiksmo plants, kiekvieno iš ju keliamiems iššükiams pasitikti autoriai nustate bendras strategines kryptis. Tarp numatomu igyvendinti pavyzdini ( projekru yra šie: l) de facto standarto, skirto kultüros kūriniu ir gamtines medžiagos rinkiniı teikimui suvestiniams katalogams ir skaitmeninems saugykloms, rengimas derinant CDWA Lite ir nusetumdat XML schemas; 2) CCO taikymas igyvendinant Architektūros istoriku draugijos Architektüros išteklin archyvo (SAHARA) projektq, skirtq nuotraukt, kuriose fiksuojama pasaulio architektūra ir kultürinis kraštovaizdis, bendro elektroninio archyvo kūrimui. SAHARA projekto metu buvo parengtas katalogavimo sablonas, skirtas naudotis mokslininkams ir bibliotekininkams; 3) CCO kartu st kitomis gairémis taikymas bibliotekose sudaromiems kultüros küriniu irašams.

Besikuriančios katalogavimo praktikos, kuri grindžiama CCO, padarinys yra irašu parengtı i LAM (bibliotekos / archyvai / muziejai) integruotos prieigos terpę orientuotu nuzieju it vaizdt biblioteku bendruomenés. gausa. Autoriai svarsto, kokiq itaka katalogavimo sprendimai (pvz., skirtingos „kūrinio" koncepcijos) gali daryti siame kontekste rengiamu irašu konvergencijai.

Reikšminiai žodžiai: katalogavimo taisyklès; kultūros objektai; CCO.

Ivadas

Bỉbliotekoms būdinga ilgametẻ tradicija, kuri kartu yra ir jų misijos sèkmę lemianti pareiga - užsiimti žiniı ir ištekliu globa, dokumentavimu, apsauga, priežiūra ir viešos prieigos prie ju teikimu. Nusistovejusių ir patvirtintu standartı taikymas yra vienintelis būdas, galintis užtikrinti šios veiklos sékmę ir tvarumą. Tačiau biblioteku bendruomené pripažista, kad kultūros paveldo rinkinių dokumentavimas ir prieigos prie jų tobulinimo priemonès turi pasižymèti 
universalumu ir lankstumu, kad atitiktų vis didèjančius technologiju plètros sąlygojamus reikalavimus ir tinklo teikiamas galimybes. Katalogavimas - sritis, kurią veikía išaugę ivairialypès vartotojų auditorijos lūkesčiai, susiję su rinkinių atskleidimu ir išteklių naudojimu, ir kuri atitinkamai prie šių lūkesčiu prisitaiko. Ryškus tokio prisitaikymo pavyzdys yra dokumentas, skirtas ištekliu aprašui ir prieigai prie ju, RDA: Resource Description and Access ${ }^{1}$, pakeitęs AACR2. Svarbu tai, kad RDA rengẻjai nesiekia iš naujo sukurti bibliografinei prieigai skirto duomenц turinio standarto, o remiasi AACR2 ir sékminga jų igyvendinimo patirtimi.

Pastaraji dešimtmetị buvo iškelta nemaža standartais grindžiamu iniciatyvu, kurios ne tik remiasi dabartiniu metu galiojančiais standartais, bet ir peržengia bibliotekas, archyvus ir muziejus skiriančią takoskyra, kurią sąlygoja skirtingi rinkiniџ dokumentavimo ir atskleidimo tinklo terpejje būdai. Vienas iš tokių pradedamų taikyti praktiniu metodu kurio atsiradimą nulèmè tai, kad nebuvo duomenų turinio standarto, skirto kultūros kūrinių ir ju vaizdo pakaitalu aprašui, dokumentavimui ir katalogavimui, ir kuriame pripažjstama, kad AACR2 tik iš dalies užpildo ši vakuuma, yra vadovas Calaloging Cultural Objects: a Guide to Describing Cultural Works and Their Images $(\mathrm{CCO})^{2}$.

CCO iniciatyva (Vaizdo išteklių asociacijos fondo (Visual Resources Association Foundation) projektas, pradètas $2001 \mathrm{~m}$.) pateikia meno kūrinių aprašo gaires, ji grindžiama $V R A$ Core $4.0^{3}$ ir Categories for the Description of Works of Art (CDWA) ${ }^{4}$ elementu rinkiniais. Tačiau visai kitaip negu pastarosiose dviejose schemose, $\mathrm{CCO}$ pasitelkiamos tipinès sąvokos, kurios gali būti vartojamos taikant kitus metaduomenц elementı rinkinius (pvz., Dublin Core, MODS, MARC ${ }^{5}$ ). Kultūros paveldo bendruomenè nèra parengusi gairiu (tokiu kaip bibliografams skirtos AACR), kurios atitiktu specifinius ir neretai išskirtinius unikalių kultūros objektu aprašo reikalavimus. Kataloguotojai, aprašydami kultūros kūrinius, priima sprendimus, remdamiesi savo pačiu supratimu, kaip turi būti apibūdinamas vienas ar kitas meno kūrinys. CCO yra duomenų turinio standartas, kurio paskirtis - padèti priimti sprendimus kataloguotojams ir kultūros paveldo sistemų kūrèjams. Gausẻjant specifinèms bendruomenèms skirtų metaduomenų standartu, vis aiškiau buvo suvokiama, kad $\mathrm{CCO}$, kuriame nustatoma bendra kultūros kūriniu aprašo metodika, galètų būti skirtingas bendruomenes siejančia grandimi.

Nuo pat savo atsiradimo pradžios CCO laikomas ilgai lauktu katalogavimo taisyklių šeimos nariu. Jo itaka nepaiso geografiniu ir organizaciniu ribų. Pavyzdžiui, $\mathrm{CCO}$ buvo rekomenduota naudoti didelems agreguotoms duomeny bazèms, tokioms kaip California Digilal Library Shared Image Service ${ }^{6}$ ir Mellon ARTstor ${ }^{7}$ skaitmeninès bibliotekos prieglobos programa. CCO itrauktas i NISO A Framework of Guidance for Building Good Digital Collections ${ }^{8}$ duomenu turinio standartu sąrašą. CCO peremè ir tarptautiniai projektai, pvz., Bulgarijos kultūros istorijos paveldo elektroninis katalogas ${ }^{9}$, Centro de Documentación de Bienes Patrimoniales (Čilè) ${ }^{10}$ ir Berlyno valstybiniai muziejai / Muziejų mokslinių tyrimu institutas ${ }^{11}$. Ir galiausiai, CCO padare itaką RDA, nes šis konceptualus modelis buvo kuriamas atsižvelgiant i ištekliu aprašo standartus, rengiamus už bibliotekı ribų.

Besikuriančios $\mathrm{CCO}$ grindžiamos katalogavimo praktikos padarinys yra įrašu, parengtu i LAM (library / archive / museum) integruotos prieigos terpę orientuoty muziejų ir vaizdų bibliotekц̨ bendruomenès, gausa. Naujieji irašai padarys šių istaigu katalogus tobulesnius, nes CCO taikymas palengvina keitimąsi metaduomenimis, tačiau toje pačioje sistemoje esantys paveldèti irašai gali sukelti kai kurių idomiu dilemų. Pavyzdžiui, gali atsirasti seniau parengtı "horizontalių" irašu ir hierarchiniu irašu sudètingiems küriniams priešprieša, dilemos dèl „kieno" ir „apie ką", taip pat gali būti ịvairiai suvokiama „kūrinio" sq̨voka. Pastaraja problema gali sunkinti ir netinkamas FRBR taikymas ${ }^{12}$.

Naujame keitimosi muziejų duomenimis tyrimo projekte Museum Data Exchange ${ }^{13}$ CCO taikomas analizuojant didelius duomenu, automatiniu būdu surinktu iš muzieju duomenu baziı, telkinius. Projektas finansuojamas Andrew W. Mellon fondo, o vykdomas OCLC RLG programy partnerystès ribose. Projekto vadovas Günter Waibel (OCLC) pastebejo: „Nors jame [projekte] naudojama ta pati duomenu struktūra ( $C D W A$ Lite XML), visi projekto dalyviai suvokia, kad taisyklès, kuriu laikosi jvairios istaigos, užpildydamos šią duomenu struktūrą duomenu turiniu, gali labai skirtis. Taikyti Cataloguing Cultural Objects tampa vis labiau iprasta, tačiau duomenimis, galimas dalykas, jau buvo gana aktyviai keičiamasi dar iki šio duomenų standarto atsiradimo, jau nekalbant apie jo taikymą vietos reikmèms. "it/4

Apžvelkime tris skirtingas $\mathrm{CCO}$ taikymo sritis, iliustruojančias, kaip šis vadovas gali suteikti bendra pagrindą kultūros paveldo katalogavimui.

\section{CCO taikymas kultūros objektų metaduomenu} darninimui: $C D W A$ Lite ir museumdat

Unikali CCO ypatybė ta, kad ji galima taikyti kultūros kūrinių ir ju vaizdo pakaitalı katalogavimui, nesvarbu, kokios duomenu struktūros dalyvauja rinkiniı̨ valdyme ir kokiose isstaigose šie kūriniai saugomi. CCO pripažistama, kad muziejuose, bibliotekose, archyvuose ir vaizdu bibliotekų rinkiniuose saugomi unikalūs kultūros kūriniai arba ju kopijos ir kad nuotolinès prieigos prie šių kūrinių teikimas interneto terpèje tampa vis svarbesne visų šiu 
istaigu pareiga. Dar viena neseniai iškelta iniciatyva, kurios atsiradimą nulèmè prieigos prie unikalių kultūros kūriniu nebuvimas, tiksliau - tinkamo techninio sprendimo, palengvinančio tokią prieiga, būtinumas, yra $C D W A$ Lite ${ }^{15}$.

CDWA Lite - tai XML schema, skirta esminiams meno ir materialinès kuitūros kūrinių irašams koduoti. Jos paskirtis - būti priemone, igalinančia jstaigas nesudètingu būdu teikti rinkiniy informacija suvestiniams katalogams igyvendinama, remiantis galiojančiais standartais. $C D W A$ Lite grindžiama Categories for the Description of Works of $A r$ (CDWA) pateiktais duomenu elementais ir gairemis, nustatančiais kultūros kūrinių ir vaizdų dokumentavimo ir informacijos apie juos organizavimo ribas. Jose $C D W A$ Lite elementams užpildyti naudojamų duomenų atrankai, sutvarkymui ir formatavimui palengvinti rekomenduojama laikytis $\mathrm{CCO}$ gairių. $C D W A$ Lite schema ir gairès skatina pasitelkti kontroliuojamus žodynus ir autoritetinius duomenis, o metaduomenų irašu pristatymas ir keitimasis jais atliekamas natudojant metaduomenų automatinio surinkimo protokolą Open Archives Initiatives Protocol for Metadata Harvesting (OAI/PMH) ${ }^{16}$.

Standartais grindžiamos $C D W A$ Lite iniciatyvos atsiradimą paskatino muziejų bendruomenei iškilęs aiškus poreikis taikyti veiksmingesnį ir tvaresni modeli skirtą teikti rinkinius suvestiniams katalogams ir skaitmeninėms saugykloms. CDWA Lite kūrẻjai suvokè būtinybę parengti unikaliems kultūros kūriniams skirtą duomenų struktūrą, kurios techninis formatas leistu išreikšti šiuos duomenis kompiuteriniu formatu. Jie suprato, kad būtina rasti sprendim‡, kaip išvengti papildomų išlaidı, kurios paprastai susijusios su teikimu suvestiniams katalogams; sukurti metodal kurị taikant būtụ galima teikti naujausią tikslią informaciją apie interneto terpèje prieinamus kūrinius; formuoti požiūri, kad duomenц integralumą ir tikslumą būtina užtikrinti jau pradinjame rinkinio šaltinyje arba saugyklojc; taip pat sukurti mechanizma, suteikianti vartotojui galimybę grižti prie savoje aplinkoje esančio ištekliaus, kur būtł galima išsamiau susipažinti su meno kūriniu platesniame rinkinio, kuriam šis kūrinys priklauso, kontekste.

Duomenų struktūros, turinio, reikšmès ir techninio formato standartt perémimas specialiai ,supaprastinamas", taip skatinant net mažas j̣stajgas juos taikyti katalogavimuj, elektroninei leidybai ir metaduomenų pateikimui bei ši taikymą palengvinti. Tai leidžia parengti ištisą sprendimų, supaprastinančių standartų taikymą, paketą. Todèl dar labiau padideja rinkiniu sklaidos galimybès.
$C D W A$ Lite sudaro 22 elementai, iš kuriụ 19 skirti aprašomiesiems metaduomenims ir 3 -administraciniams metaduomenims; būtini tik 9 elementai. Šie elementai atspindi esminę tradiciškai pateiktamą aprašomają dokumentaciją apie kultūros pavęldo rinkinius sudarančius kūrinius.
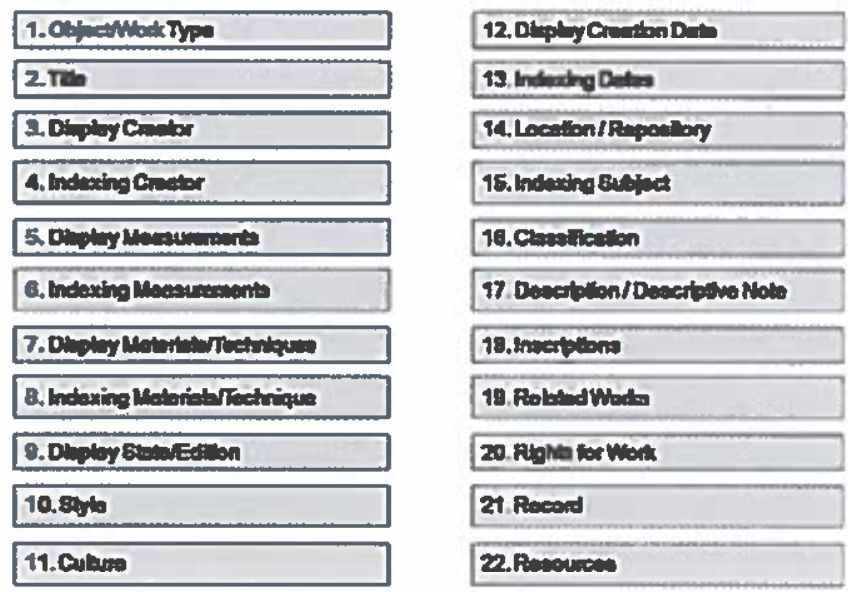

CDWA Lite elementu rinkinys

$C D W_{A}$ Lite unikali tuo, kad joje atskiriami atvaizdavimo ir indeksavimo elementai, kaip siūloma CCO rekomendacijose. CCO rekomenduoja, kad tam tikri duomenys, skirti pateikti galutiniam vartotojui, būtụ suglaudinami. Norint galutiniam vartotojui pateikti reikšmingą aprašomąą informacija, gali tekti sujungti skirtingu laukụ reikšmes arba pašalinti tam tikrą vidaus reikmèms skirtą neskelbtiną informaciją ar administravimo duomenis. Be to, parodymo duomenims skirtuose laukuose numatyta galimybè išreikšti meninei informacijai paprastai büdingą neapibrèźtumą ir dviprasmiškumą. Antra vertus, indeksavimo elementu reikšmès tradiciškai atitinka kontroliuojamų žodynų afba autoritetinių duomeny reikšmes, tai užtikrina nuoseklumą ir tikslumą bei veiksmingą paieška. Indeksavimo elementai $C D W A$ Lite atributams leidžia priskirti atitinkamus URI (termino šaltinio ir termino šaltinio identifikatorius), taip suteikiant galimybę identifikuoti terminą platesniame kontroliuojamo žodyno kontekste.

Pateiksime CDWA Lite taikymo pavyzdi, pasitelkdami paveikslą iš J. Paul Getty muziejaus rinkinių, automatiniu būdu surinktą ir ikeltą $\mathrm{i}$ skaitmeninę $A R T$ stor biblioteką naudojant CDWA Lite. 


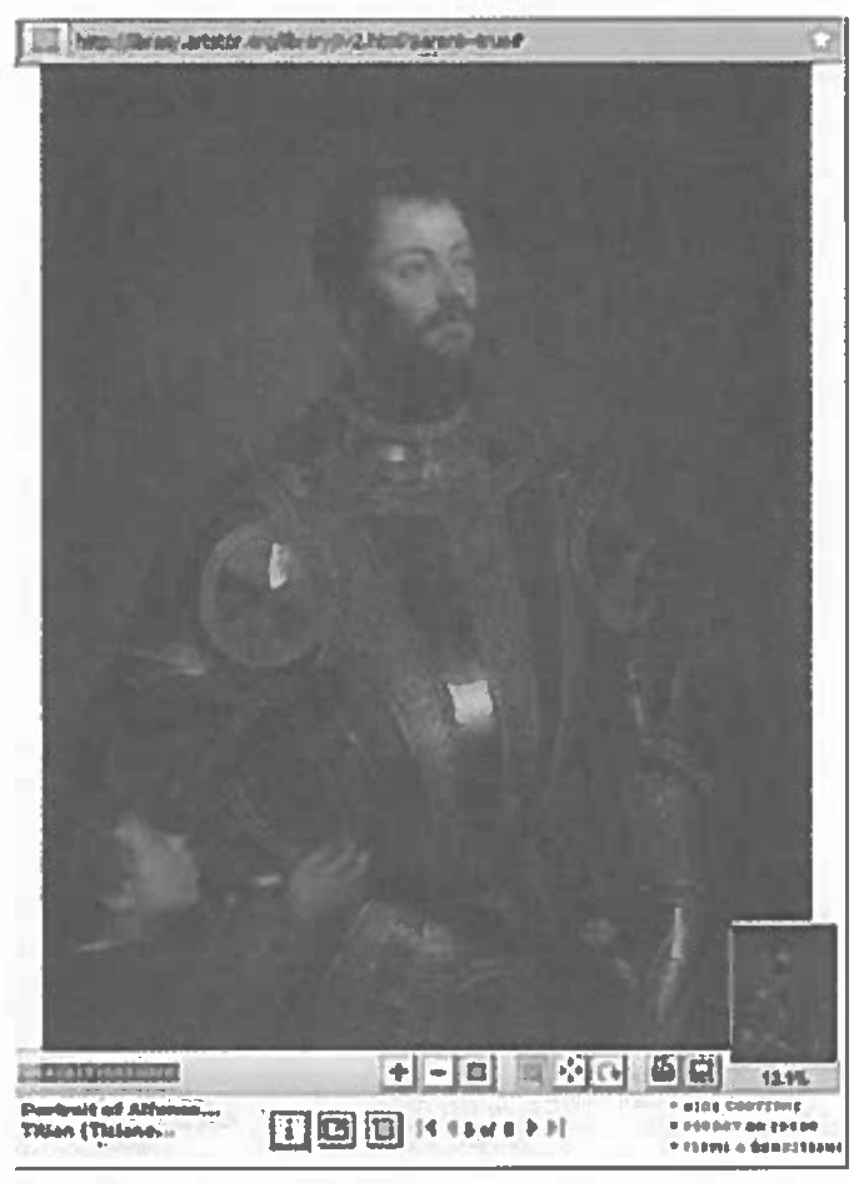

\begin{tabular}{|c|c|}
\hline Creator & $\begin{array}{l}\text { Titian (Tiziano Vecello) (Italian, about } 1487 \text { - } \\
\text { 1576) }\end{array}$ \\
\hline Gulturo & Italian \\
\hline Title & $\begin{array}{l}\text { Partrait of Alfonso d'Avalos, Marchese del Vasto, in } \\
\text { Armor with a Page }\end{array}$ \\
\hline Work Type & Paintings \\
\hline Date & probably January - February 1533 \\
\hline Material & Oil an canvas \\
\hline Measurements & Unframed: $110 \times 80 \mathrm{~cm}(435 / 16 \times 311 / 2 \mathrm{in})$. \\
\hline Repository & $\begin{array}{l}\text { The 1. Paul Getty Museum at the Gotty Center } \\
2003,486\end{array}$ \\
\hline Felated Item & 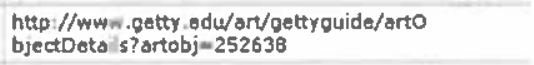 \\
\hline Subject & $\begin{array}{l}\text { Comthanding Officers } \\
\text { Alfonso d'Avalos, Marchese del Vasto }\end{array}$ \\
\hline Collection & The Image Galery \\
\hline Source & Data From: I. Paul Getty Museum \\
\hline Rights & 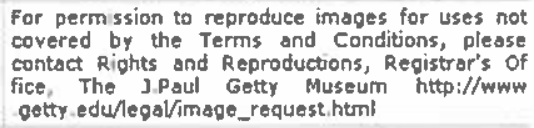 \\
\hline Downlosd Size & 1024,1024 \\
\hline
\end{tabular}

J. Paul Getty muziejaus informacijos valdymo sistemoje pateikiama išsami aprašomoji informacija apie ši paveikslą Tačiau CDWA Lite schema nesiekiama atkurti visų kūrinio aprašomujų elementu, veikiau - pateikti minimalų duomenu reikalingu lengvai prieigai prie ištekliaus „vieningoje“ aplinkoje, rinkinị. Iš šio pavyzdžio matyti, kad agregatoriui (ARTstor) buvo prieinama ribota aprašomoji ir administracine informacija apie ši Ticiano paveikslą. ARTstor, kurios dèmesio centre yra kūrèjo duomenys, $C D W A$ Lite elementą „Kürẻjo atvaizdavimas“" pateikia taip:

Titian (Tiziano Vecellio) (Italian, about 1487-1576)

Getty muziejaus $A R T$ stor bibliotekai pateiktas irašas, be šio elemento, apima ir kūrèjo indeksavimo elementus. Schemoje jie koduojami taip:

<cdwalite:displayCreator> Titian (Tiziano Vecellio) (Italian, about $1487-1576)</$ cdwalite:displayCreator $>$

$<\mathrm{cdwalite}$;indexingCreatorSet>

$<$ cdwatite:nameCreatorSel $><$ cdwalite:nameCreator type $=$ "personalName" termsource="ULAN"termsourceID= "ulan500031075">Titian</cdwalite: nameCreator> $<$ cdwalite:nameCreatorSet>

$<$ cdwalite:nameCreatorSel $><$ cdwalite:nameCreator type= "personalName" termsource="ULAN"termsource ID= "ulan500031075"> Vecellio, Tiziano </cdwalite; name Creator>

$<$ cdwalite:nameCreatorSet>

$<$ cdwalite:nationalityCreator>Italian</cdwalite: nationality Creator $>$

$<c d$ walite:vitalDatesCreator birthdate $=" 1487$ " deathdate $=$ "1576"> about 1487 - 1576

$</$ cdwalite:vitalDatesCreator $>$

$<$ cdwalite:genderCreator $>$ male </cdwalite:genderCreator $>$ $<$ cdwalite:roleCreator termsource="AAT" termsourceID= "aat300025136">painter $</$ cdwalite:roleCreator $>$

$</$ cdwalite;indexingCreatorSet $>$

$</$ cdwalite:indexingCreatorWrap $>$

Indeksavimo elementai apima informacija, palengvinančią paiešką, taip pat padedančią agregatoriams filtruoti ir rūšiuoti paieškos rezultatus. J. Paul Getty muziejuje dažniausiai vartojami kūrèjo duomenys iš autoritetinio meninjnku failo, véliau nustatoma jų sutaptis su $C D W A$ Lite indeksavimo ir atvaizdavimo elementais.

Be to, verta dar karta paminèti, kad CDWA Lite nurodo, kaip tinkamiausiai užpildyti naudojamus $\mathrm{CCO}$ elementus. Pavyzdžiui, elementui „Kūrẻjo atvaizdavimas" $C D W A$ Lite rekomenduoja:

,[Duomenų reikšmès] formuluojamos pagal $\mathrm{CCO}$ ir CDWA duomenų turinio taisykles, skirtas kūrējo apibūdinimui, jei būtina, jos gali būti sudaromos sujungiant kūrèjo indeksavimo elementus. Vardas pateikiamas tiesiogine tvarka, jei tai imanoma, nors priimtina ir inversija. Itraukiama tautybè ir gyvenimo datos. Nežinomiems küréjams 
vartojamos sutartinès frazès, pavyzdžiui: unknown, unknown Chinese, Chinese arba unknown 15th-century Chinese. ${ }^{* 17}$

$C D W A$ Lite sékmingai taikoma kaip rinkiniu metaduomenu nesudètingo teikimo jungtiniams ištekliams priemonè. Tai, kad šioje schemoje atsižvelgiama i CCO gaires, suteiké galimybę ijos struktūrą tinkamai integruotis „kūrinio“ sq̨vokai, taip pat ją tinkamai naudoti integruotai prieigai. To pasekmė yra beprasidedanti bendrai kuriamo unikalių objektų aprašo konvergencija tinklo terpejje, ypač formuojantis muzieju, bibliotekų, archyvu ir vaizdu bibliotekų teikiamu (LAM) išteklių sankaupoms.

Per palyginti trumpa CDWA Lite schemos gyvavimo laikotarpi ivyko daug dalyku, susijusių su jos naudojimu, diegimu, analize ir plačiai paplitusiu taikymu. Buvo sukurta nauja programinè iranga OAICatMuseum, grindžiama OCLC atviraja programine iranga $O A / C a t$, igalinanti automatiniu būdu surinkti $C D W A$ Lite XML ịrašus taikant OAl-PMH modeli, kuriam metaduomenų irašams surinkti kaip ,minimalus bendras vardiklis" būtina Dublin Core XML schema ${ }^{18}$. Rinkinių valdymo sistemų pardavẻjai pradejjo ieškoti būdu, kaip eksportuoti $C D W A$ Lite XML įrašus iš ju sistemų ir igalinti jų automatini surinkimą taikant OAI-PMH ${ }^{19}$. Skaitmeninès saugyklos ir portalai pradeda automatiniu būdu rinkti $C D W A$ Lite ịrašus arba sudaro sąlygas įrašų teikimui $C D W A$ Lite formatu ${ }^{20}$. Ivairios pasaulio bendruomenés pradeda vertinti $C D W A$ Lite svarbą ir naudojimosi ja paprastuma, tai rodo Taivane igyvendinamas projektas Musefusion ${ }^{21}$ ir projektas Museum Data Exchange Project. Pastaroji iniciatyva subūrẻ muziejus - RLG partnerius -CDWA Lite schemos taikymą ir diegimą palengvinsiančiu priemonių komplektui sukurti.

Vienas iš didžiausių $C D W A$ Lite plétros pasiekimų yra Vokietijos muzieju asociacijos dokumentavimo komiteto sukurta XML schema museumdat, kuri praplečia $C D W A$ Lite schemą, taip ją labiau pritaikydama gamtos ir kultūros istorijos rinkiniams ir priderindama jos elementus prie $i$ ivykius orientuoto CIDOC konceptualaus pavyzdinio modelio (ISO 21127: 2006) ${ }^{22}$. Musetumdat CDWA Lite schema papildo ivykiams skirtu elementu, taip suteikdama jaj semantinị pagrindą ir galimybę traktuoti su objektu susijusius ivykius. Todél bendras elementụ skaičius padidẻja iki 23, taip pat iš naujo perkonfigūruojami elementai, kad optimaliai atitiktụ i ivykius orientuotą koncepcija. Būtinuju elementụ skaičių museumdat sumažina iki triju ${ }^{23}$.

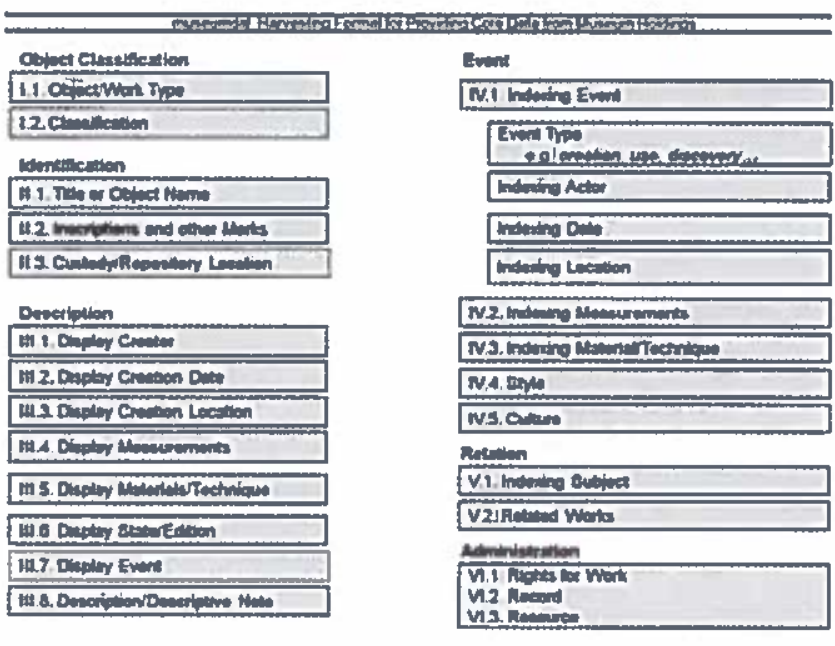

Museumdat elementụ rinkinys

Musetumdat sudaro penkios pagrindinès kategorijos, tai atitinka CIDOC CRM pagrindiniu metaduomeny elementų rinkinị. Schemoje taip pat išskiriama administravimo elementı̨ kategorija, ji papildyta formatuj daugiakalbiškumo suteikiančiais atributais, taip pat sudaroma duomenu konversijos kontrolès galimybẻ. Nepaisant šių pakeitimu, musetimdat labai nenutolo nuo CDWA Lite esmès ir paskirties. Pavyzdžiui, museumdat specifikacijoje, kur tinka, atsižvelgiama i $\mathrm{CCO}$ gaires elementams užpildyti, jame taip pat išlaikoma tiek atvaizdavimo, tiek indeksavimo elementų naudojimo galimybè.

Mtsseuntdat XML schema buvo paskelbta $2007 \mathrm{~m}$., ir per trumpą laiką naudojimosi ja mastai ir doméjimosi ja entuziazmas pasiekè $C D W A$ Lite lygi. Ja taiko ne tik Vokietijos muzieju bendruomené - ji tapo standartiniu atvaizdavimo formatu, kuriuo muzieju objektu duomenys perduodami i Bibliorheken Archive und Museen (BAM) portalą, o tai leidžia atlikti paiešką visuose Vokietijos biblioteku, archyvu ir muzieju rinkiniuose ${ }^{24}$. Ją taip pat taiko regioninių muziejų tinklas Digicult Schleswig-Holstein ir vaizdu archyvas Bildarchiv Foto Marburg. Ji laikoma pripažintu Europeana - Europos Komisijos finansuojamo projekto, kurio dẻka įmanoma paieška visose Europos kultūros rinkiniuose - metaduomenцุ formatu ${ }^{25}$.

Naudojantis CDWA Lite ir museumdat XML schemomis

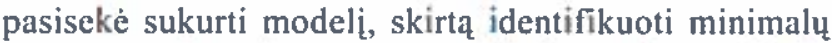
duomenụ kiekí, būtiną išteklių atskleidimui palengvinti, taip pat rastas sprendimas, kaip istaigoms nekliudomai teikti savo rinkinius suvestiniams katalogams ir skaitmeninèms saugykloms. Abiejų šių iniciatyvı kūrẻjai pripažino, kad didèjantys su visuotiniu išteklių suradimu susiję lūkesčiai reikalauja rasti būdų, kaip suteikti galimybę kiekvienam norinčiam dalyvauti nuotolinés prieigos prie kultūros paveldo kūrime. Tam sẻkmingai gali būti taikomi 
galiojantys standartai. Šioje srityje lyderio pozicijas užima $C D W A$ Lite, tačiau, pradèjus taikyti museumdat, prasiplèté aprèptis, nes atsirado daugiau galimybių itraukti skirtingus rinkinius, taip pat igyta daugiau lankstumo dokumentuojant kultūros paveldą - tapo imanoma aprašyti sąvokas ir santykius.

$C D W A$ Lite kūrẻjai nedelsdami pripažino musetımdat pasiekimus sujungiant pažangiausius CIDOC CRM i ¿vykius orientuotos, daugiadisciplinès koncepcijos aspektus ir $C D W A$ Lite santykini paprastumą bei pagrindinius jos elementus. Taikyti schemas kiekvienos iš ju specifinès paskirties ribose gali būti naudinga ir rezultatyvu. Tačiau patrauklia ir daug galimybių teikiančia alternatyva pasirodé CDWA Lite ir museumdat pasiekimı sujungimas i vieną bendrą schemą. Buvo suburta CDWA Lite / museirmdat darbo grupė, susidedanti iš pagrindinių abiem iniciatyvoms atstovaujančių suinteresuotų asmenų. Jai buvo pavesta parengti naują schemą, kuri būtu grindžiama $C D W A$ Lite ir apimtų museumdat pasiekimus. Galutinis rezultatas būtụ schema, kuria naudojant informacija apie bibliotekų, archyvu, muzieju ir vaizdu biblioteku rinkinius būtu gaunama standartizuotu formatu, igalinančiu integruoti juos i tinklo terpę ir palengvinančiu ištekliaus atskleidimą ir suradimą.

CDWA Lite ir museumdat darninimo tikslas yra sukurti kultūros ir gamtos istorijos rinkinių teikimo suvestiniams katalogams ir skaitmeninems saugykloms de facto standarta. Parama, kurią šioms dviem iniciatyvoms suteiké bendruomenè (pardavējai, agregatoriai ir išteklius kaupiančios jstaigos), taip pat $C D W A$ Lite / museumdat darbo grupės inašas vienijant pastangas ir kuriant bendrą schema, liudija, koks gali būti galiojančių standartų ir naujụ principu vaidmuo ieškant skirtingı sektorių ribas peržengiančiı sprendimu bendram tikslui - atskleisti išteklių visiems.

\section{Mokslininkai ir katalogavimas: SAHARA vaizdu archyvas}

$2008 \mathrm{~m}$. kovo mėn. Architektūros istoriku draugija (Society of Architectural Historians - SAH) gavo Andrew W. Mellon fondo dotaciją SAH architektüros ištekliu archyvui (Society of Architectural Historians Architecture Resources Archive - SAHARA) - dinamiškai elektroninei mokslo ir mokymo tikslams skirtai architektūros ir kraštovaizdžio vaizdų bibliotekai - kurti ${ }^{26}$. Apie tokio šaltinio būtinumą buvo kalbama ir Mokslinès komunikacijos instituto (Scholarly Communication Institute) sesijoje (SCI 4), $2004 \mathrm{~m}$. vasarą surengtoje Virdžinijos universitete (Šarlotesvilis, JAV, Virdžinijos valstija) ${ }^{27}$, taip pat paremtoje Andrew W. Mellon fondo. Sesijos tikslas buvo suteikti galimybę SAH vadovams, architektūros istorikams, bibliotekininkams, leidejjams, technologijų specialistams ir aukštojo mokslo vadovams studijuoti, plètoti ir taikyti institucines bei $\{$ atskiras disciplinas orientuotas strategines kryptis, siekiant tobulinti architektūros istorijos srities mokslinius ryšius dabartinès skaitmeninès revoliucijos sąlygomis.

Mokslinès komunikacijos instituto Virdžinijos sesijos rezultatas buvo dvi SAH draugijai suteiktos dotacijos. Pirmosios paskirtis buvo parengti bandomają elektroninès Journal of the Society of Archilectural Historians versija. Antroji skirta SAHARA, tikintis, kad mokslininkai, bibliotekininkai ir istaigu vadovai suvienys pastangas ir sukurs bendrą nuotolini išteklių, praturtinsianti architektūros istorijos mokslą ir tapsianti dar vienu bendradarbiavimo modeliu, skirtu vaizdo išteklių specialistų bendruomenei ir meno bei architektūros bibliotekoms. Pirmą karta, užuot kûrus vienas kitą atkartojančius skaitmeninius archyvus kiekviename universitete, SAHARA leis kartu sukurti ypač autoritetingą visą pasaulị aprèpiantị ištekliu, kuris skatins nauju moksliniц tiriamuju ir akademiniц publikaciju atsiradima, taip pat prisidès prie universitetinio mokymo tobulinimo.

Tikimasi, kad SAHARA pakeis vaizdo išieklių istaigų ir jose dirbančiu meno bei architektūros bibliotekininku veiklos pobūdị. Užuot kaupę atskirus, vienas su kitu nesusijusius architektūros vaizdu rinkinius kiekvienoje istaigoje, mokslininkai ir bibliotekininkai teiks vaizdus ir metaduomenis SAHARA - plačiai prieinamam bendram ištekliui. Bus iki minimumo sumažintas dubliavimas kaupiant rinkinius, dèl to taip pat sumažès originalaus katalogavimo dubliavimo. Tai yra ilgametis vaizdo ištekliu bendruomenès siekis, ir SAHARA kaip tik yra šios koncepcijos išbandymo modelis.

SAHARA - tai partneriu bendrija, vienijanti platu asmeny ir istaigu ratą. Vieną iš partnerių grupiu sudaro SAH vadovybės nariai: vykdomoji direktorè Pauline Saliga, prezidentas Dietrich Neumann ir pirmoji vicepirmininkẻ Dianne Harris. Pradiné biblioteku-SAH partneriu-grupé (Brown universitetas (Providensas, JAV), Masačusetso technologijos institutas (Kembridžas, JAV) ir Virdžinijos universitetas (Sarlotesvilis, JAV)) buvo sutelkta remiantis žiniomis apie šiose aukštosiose mokyklose déstomas architektūros istorijos programas ir dideliu vaizdo išteklių bei architektūros bíbliotekininkı entuziazmu issitraukti ị šią veiklą. Technologinis partneris yra ARTstor - viena didžiausių vaizdų saugyklų, turinčiu išplétotą technologinę infrastruktūrą ir organizacinę patirti bei personalą, pajègu prisidèti prie tokio projekto, kaip SAHARA.

SAHARA bus recenzuojamas išteklius, panašiai kaip mokslo draugijos žurnalas. Vienas is siekiu yra padèti puoselèti idèją kad vaizdinis turinys yra tokia pat vertinga 
moksliné priemoné kaip tekstinis turinys ir kad individualus mokslininkų požiūris, kurịjie perteikia kartu su pateikiamais vaizdais, tiesiogiai atspindi jų nuomonę apie pačius aplinkos statinius. SAHARA rinkinị sudarys dvi iš dalies sutampančios vaizdu grupés: „Dalyviu rinkinys" ir "Redaktoriaus pasirinktas rinkinys". Bet kuris SAH narys gali siųsti savo vaizdus i SAHARA, jei tik jie atitinka pagrindinius techninius kokybès reikalavimus. Vaizdai bus talpinami "Dalyviu rinkinyje". „Redaktoriaus pasirinkto rinkinio" vaizdai bus atrenkami iš „Dalyvių rinkinio“ atsižvelgiant $i$ techninę kokybę, taip pat tokius kriterijus, kaip turinio unikalumas ir jo atitikimas tı̨ sričiŁ̧, kurios būtinos rinkiniui plésti. Recenzavimą ir atranką atliks redakcinès grupés, sudarytos is̆ SAH mokslininkų ir bibliotekininkų - SAH partneriu, kurie bus „sričių redaktoriais“, pasiskirsčiusiais pagal atskiras geografines sritis ir istorinius laikotarpius (pvz., Italijos Renesanso architektūra).

Pirmaisiais metais svarbiausias partnerių uždavinys buvo sukurti ¡kélimo priemonę, sudarančią galimybę mokslininkams patiems siųsti vaizdus, sukurti metaduomenis apie juos ir galiausiai šl turini pateikti SAHARA rinkiniams. Šs modelis, kai mokslininkai savo veikla prisideda prie rinkiniụ is prieigos prie jụ kūrimo, yra naujoviškas, skatinantis iš naujo ivertinti mokslininku ir bibliotekininkų vaidmenị rinkinio kūrime ir katalogavime. Mokslininkai yra savo sričių žinovai; todèl manome, kad SAHARA kuriančiu mokslininku profesinẻ patirtis praturtins vaizdụ katalogavima, praplẻs prieigos prie jụ galimybes ir padès kurti aukštos kokybẻs metaduomenis. Atskiru sričių redaktoriai taip pat perteikia mokslinę patirtị, kuri recenzuojamam rinkiniui SAHARA suteikia būdingo kokybiškumo ir autoritetingumo.

Nors CCO standartas taikomas aplinkos statinit katalogavimui, mokslininkai - mūsų kolegos iš SAHARA nežinojo, kad yra priimti jiems tinkantys katalogavimo standartai. Buvo laikomasi nuomonés, kad standartai (tie, kurie parengti bibliotekininku) nèra pakankamai pritaikyti jų sričiai ir juose neatsižvelgiama į specifiką terminų, kurie gali būti vartojami paieškł̨ atliekančių architektūros istorikų (pavyzdžıui, „cancello“, Romos imperijos ankstyvuju krikščionių šventyklose paplitęs altoriaus pertvaros tipas). Todẻl su SAHARA mokslininkais ir bibliotekininkais buvo išsamiai diskutuojama apie architektūros vaizdams tinkamus metaduomenis. Mokslininku ir bibliotekininku grupé, parengiamuoju etapu apsvarsčiusi reikalavimus, mokslininkı̨ keliamus aplinkos statinių vajzdu turinio paieškai, ir tai, kokie metaduomenys būtinni sẻkmingam turinio atskleidimui, parengè pradinę metaduomeny schemos koncepciją. Metaduomenų schemai keliami didžiuliai reikalavimai. Buvo būtina suderinti pastangas, skirtas skatinti mokslininkus jsitraukti i kokybiškų skaitmeniniu ištekliu kūrimą, ir vaizdu katalogavimo procesq palengvinančių būdu paieškas. Nors SAHARA projektu siekiama pakeisti mokslininkų darbo jpročius, tapti kvalifikuotais kataloguotojais jie paprasčiausiai negali. Schema taip pat turi atitikti kataloguotojų ir dirbančiuju su kompiuteriy sistemomis reikalavimus: jos duomenys turi būti teisingi, tinkami efektyviai paieškai ir keitimuisi. Tokio suderinamumo paieškos toli gražu nèra lengvas uždavinys, ir mes manome, kad testavimui pasibaigus pirmoji mūsų schemos iteracija bus šiek tiek pakeisla.

SAHARA šiuo metu siūlo dvi schemos ,perspektyvas“. Viena trumpa „perspektyva“ yra skirta mokslininkams atlikti juvedima, kurio metu nebūtinai turi būti pateikiami autoritetintai duomenys. Kita ,perspektyva“ gali pasinaudoti kataloguotojai arba mokslininkai, suinteresuoti išsamiu meladuomenų irašu sudarymu. Mūsų siūlomas schemos veikimo modelis būtụ toks: dalyvaujančiu ìstaigu bibliotekininkai bendrai teikia SAHARA autoritetinius duomenis ir redaguoja mokslininkų ivedamus duomenis. Atskiroms sritims bus sudaromi taip pat ir kontroliuojami žodynai, palengvinsiantys katalogavima. Kai kurie terminai, tokie kaip kūrèjų ir geografinių vietụ vardai, bus atrenkami iš ARTstor Autoritetinio vardų failo ir Šaliu vardụ failo. Susiejimas su prieinamais autoritetiniu duomenų failais ir kontroliuojamais terminais padès išlaikyti nuoseklumą ¿vedant duomenis ir sudarys galimybę mokytis tiems, kuriems trūksta katalogavimo igūdžių.

Buvo atlikta išsami schemos peržiūra, tačiau išlaikyta nuosekli susietis su VRA Core 4.0 ir CCO principais. Schemą tobulinti padejo $A R T$ stor personalas, pasidalydamas darbo su metaduomenimis patirtimi ir techninėmis žiniomis, taip pat užtikrindamas, kad schema veiks su ikẻlimo priemone. ARTstor technologai kartu su triju pirmuju partneriı istaigu programuotojais sukūré XML schemą, palengvinančią duomenų perdavima iš vietinių katalogavimo priemonių $i$ ARTstor. Tikimasi, kad ateityje teikéjai ¡kèlimo priemone naudosis išsamaus jrašo perdavimui, o ne eksportuos duomenis iš didelio skaičiaus katalogavimo sistemu $\mathrm{i} A R T$ stor, privalédami apdoroti duomenis prieš juos paskelbiant.

SAHARA schemoje naudojama nemaža CCO elementụ, tokiu kaip kūrèjas, statinio pavadinimas, kūrinio rūšsis, data, buvimo vieta, stilius, šaltinis, vaizdo tịpas, vaizdo apibūdinimas, medžiagos ir technika, matmenys, apibūdinimas, dalykas. Duomenyse apie kūrẻja galima pateikti jo tautybę, jo indèli i pastatą ar vietą ir priskyrimo informacija. Prie antrašlės gali būti pateikiamos alternatyvios antraštès, taip pat kompleksų, kuriu dalis pastatas gali būti, pavadinimai. Vietos duomenys - adresas: gatve ir namo numeris, miestas ir šalis. Architektūros moksle vis dažniau naudojamos geografinès koordinatès, todèl SAHARA numaté geogra- 
finio taško, kuriame yra pastatas ar vieta, nuorodos galimybę, pasitelkiant geografinès ilgumos ir platumos koordinates.

Vienas iš svarbiausiụ tokio ištekliaus kūrimo (t. $y$. kai dalyvauja keliolika skirtingц teikèju) aspektu yra galimybe pasinaudoti autoritetiniais failais ir kontroliuojamais terminais. Bendradarbiaudami su kolegomis iš $A R T s t o r$, susiejome „Kūrẻjo“ lauką su ARTstor Name Authority File (sudarytu Getty muziejaus ULAN pagrindu ${ }^{28}$ ). Pavadinimo laukui, kuris nesusietas su autoritetiniu failu, būdinga automatinio užpildymo funkcija, todèl, teikẻjui ̨rašius SAHARA duomenų bazèje esanti pastato ar vietos pavadinima jis bus rodomas kaip galimas pasirinkimas. Tai padès išlaikyti [rašomı duomenu nuoseklumą. Augant SAHARA turinio apimčiai, automatinio užpildymo funkcijos reikšmé didės, nes rinkinys aprẻps daugiau architektūros kūrinių.

Kituose laukuose būtina vartoti kontroliuojamus terminus. Tai tokie laukai kaip vaizdo tipas, siaura kJasifikacija (kuris šiuo atveju naudojamas kūrinio rūšiaj apibūdinti) ir šalis (parenkama iš $A R T$ Ts or šalił̨ sąrašo). Terminai šiems laukams buvo parinkti iš Getty tezauro, bendradarbiaujant SAHARA mokslininkams ir bibliotekininkams. Kūrinio rūšiu, SAHARA projekte vadinam „, siaura klasifikacija“", sąrašo rengimas buvo ilgas procesas. Daugelyje vaizdı̨ katalogavimo duomenı bazių kūrinio tūšims apibrèžti vartojamı terminu sąrašaj labai ilgi. Išskleidžiamasis šimtus terminı apimantis sąrašas būtụ labai nepatogus naudotis ir gali būti nepatrauklus teikèjams. SAHARA parengè ypač trumpa sąrašą, kuris išèjo išsamesnis, negu buvo iš pradžit sumanyta. Šiame sąraše, užuot điferencijavus statinius ar vietas pagal ju specifines funkcijas, skiriamos išsamios statinių ir vietụ kategorijos. Siuo atveju „kūrinio rūšies“ sq̨voka tapo abstraktesné ir todél tinkamesné pragmatiniams poreikiams tц asmenu, kurie nèra profesionalūs kataloguotojai.

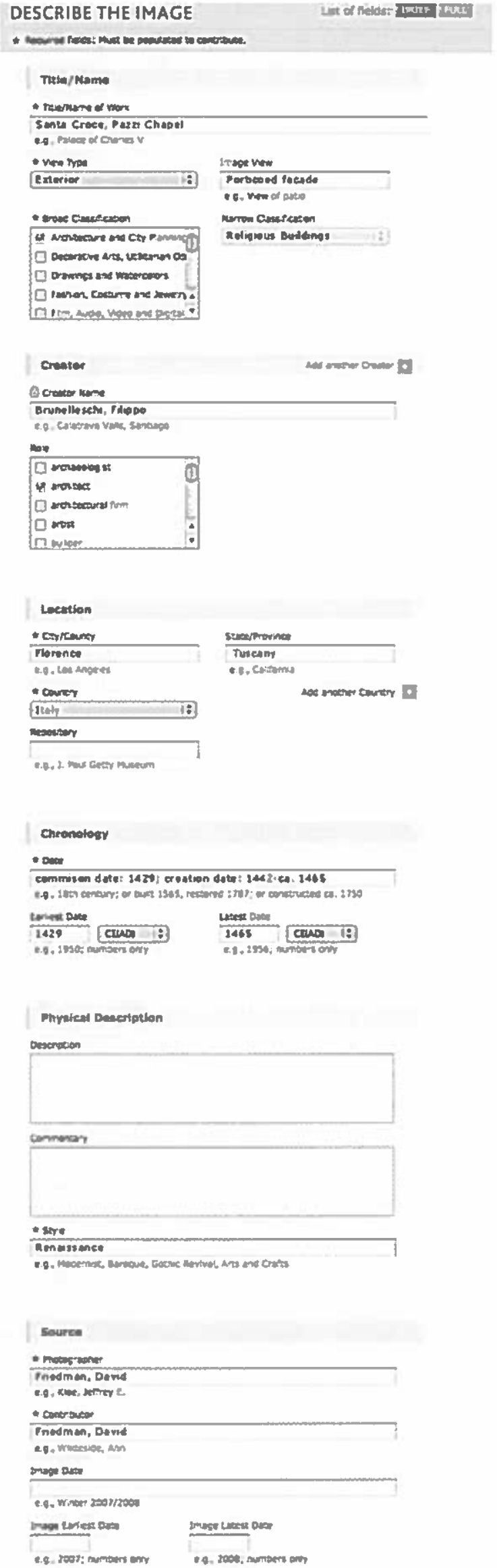


Nebūdingi CCO, tačiau atliekantys ypač svarbų vaidmeni SAHARA yra administraciniai laukai, skirti duomenims apie fotografa, vaizdų teikèj‡, taip pat autoriu teisèms ir naudojimo teisèms įrašyti. Siekdami sumažinti reikalaujamu pateikti metaduomenu skaičių, apibréžème privalomus laukus. Jie panašūs į CCO rekomenduojamus privalomus laukus: antraštè, vaizdo tipas, plati klasifikacija (palengvina paiešką didelèse skaitmeninėse saugyklose), buvimo vieta, data, stilius ir šaltinio informacija, susijusi su teikeju, autoriu teisèmis ir naudojimo teisèmis.

Diskusijose apie SAHARA projekto metaduomenis keletas mokslininkų paminèjo būtinybę neatidéliotinai sudaryti kūrinių autoritetinị vardų failą. Toks failas, pavyzdžiui, padètu atskirti ịvairius Venecijos Palazzo Corner. Daugelį metų tokị pageidavimą reiškẻ ir kultūros paveldo kataloguotojai. Kaip atsakas i tai, pagal Getty žodynų programą (Getty Vocabulary Program) sudaromas naujas tezauras Cultural Objects Name Authority (CONA) ${ }^{29}$. SAH ypač suinteresuota dalyvauti CONA sudaryme. Mokslininku patirtis ir šiuo atveju būtų reikšmingas innašas rengiant toki autoritetini faila.

Mokslininkams pradejus dalytis vaizdais ir juos kataloguoti SAHARA, vienas mums užduodamų klausimu buvo susijęs su problema: „Kq aš kataloguoju?*" Jei kataloguojamas pastatas, jo vieta yra ta geografinè vietové, kurioje jis pastatytas. Tačiau kartą viena mokslininkè, bandanti kataloguoti žemèlapị, mūsų paklausẻ: „Kokiu būdu imanoma kataloguoti toki objektą, kaip Nolli žemèlapis, jei būtina užpildyti vjetos lauką?"* Ji pastebẻjo, kad galbūt reikètų aiškiau apibrèžti, kas būtina SAHARA ir kas $A R T$ stor ir, antra vertus, kad būtina glaudesnè šiu dvieju saugyklų sąsaja ir lankstumas, turint galvoje ju turini ir jiems atliekamą katalogavimą. Ši mokslininké palieté klausima, kuri kasdien sau užduoda kataloguotojai - kaip bendrose sistemose suderinti skirtingus požiūrius i katalogavimą, kad tai būtu prasminga galutiniam vartotojui? Svarbiausi klausimai gali būti aptariami katalogavimo gairèse, tačiau turinio konvergencijos saugyklose problema turi būti sprendžiama bendromis kataloguotojų ir saugyklų turinio teikèju pastangomis.

SAHARA projektas startavo $2009 \mathrm{~m}$. balandžio $1 \mathrm{~d}$. Jo pradini rinkini, kuri teikèjai gali pildyti naudodami ịkèlimo priemonę, sudaré 9500 vaizdu. Mokslininkai teikia ir naudoja metaduomenų šablona, tajp pat pateikia atsiliepimus apie mūsı̨ sukurtą metaduomenı̨ schemą, naudojimosi šablonu ypatumus ir specifinius metaduomenų laukus. Pavyzdžiui, mokslininkai išreiškẻ nuomonę, kad vaizdo tipo terminų sąrašas per trumpas. Lygiai taip pat buvo atsiliepta ir apie siauros klasifikacijos terminų sąrašą. Šie atsiliepimai sugrąžina mus i ankstesnę diskusiją apie tai, kaip parengti pakankamai trumpus ir patogius naudotis arba gana ilgus, bet vertingus sąrašus. Po svarstymu apie metaduomenu laukus buvo nuspręsta, kad stiliaus laukas turi būti privalomas. Tačiau daugelis pastebèjo, kad reikalavimas būtinai apibréžti stiliı yra nenaudingas, nes ne visi pastatai, vietos ar kraštovaizdžiai gali būti priskiriami konkrečiam stiliui. Iš kitụ atsiliepimų aiškẻja, kad ne visai suprantama, kaip turi būti naudojami laukai, kokios reikšmès irašomos i konkrečius laukus ir kodèl prieigai prie rinkinio, kuris ateityje isivaizduojamas kaip šimtı̨ tūkstančił vaizdų sankaupa, būtina tam tikros rūšies informacija.

SAHARA projekto grupé parengė atsiliepimų žurnalą, kuris padétų priimti pagristus sprendimus dẻl siūlomų atlikti metaduomenų schemos ir laukų naudojimų pakeitimų. Šiı̨ sprendimų rezultatas būtı kitais metais daromi visiems priimtini pakeitimai. Taip pat rengiamos katalogavimo gairès, kurių bus laikomasi Architektūros istorikų draugijos bendruomenejje ir kurios, kaip tikimasi, suteiks žiniu mokslininkams bei pades kataloguoti SAHARA specialistams. Mūsu teikiamų specialiuju paslaugu dalị sudaro bibliotekininkų, kurie galètụ padèti medžiaga SAHARA teikiantiems mokslininkams suprasti metaduomenu laukus ir juos naudoti, samdymas.

SAHARA užsiima ne tik rinkinio gausinimu, bet ir moko mokslininkus kritiškai żiūrẻti i metaduomenis kaip i praktini metoda ir parinkti optimaliausią prieiga užtikrinančius metaduomenis. SAH nariams pradèjus teikti medžiaga, o architektūros ir vaizdo išteklių bibliotekininkams ịsitraukus i katalogavimo ir redagavimo veiklą, sjekiama, kad susiburtı bendra veikla užsiimanti bendruomene, kurios pagrindinis uždavinys būtų sukurti naują mokslinès veiklos modeli, skirtą architektūros istorijai. SAHARA yra vienas iš galimų mođelių, kai bibliotekininkai ir mokslininkai bendromis pastangomis apibrèžia minètas naujas veiklos sritis, gyvybiškai svarbiı patarimı̨ pasisemdami iš CCO.

\section{CCO taikymas MARC / AACR srityje}

lšgirdę, kad biblioteka savo OPAC taiko $\mathrm{CCO}$, daugelis bibliotekininkų tikriausiai paklaustų: „Kam jums to reikia?“ Argi CCO nèra skirtas vaizdo ištekliц rinkiniams ir meno muziejams, o ne bibliotekų fondams, kuriems taikomi savi duomenų standartai? Kam painjoti dvieju skirtingų sričiu standartus?

Tiesa yra tokja, kad bibliotekų fondus sudaro daugiausia publikuoti leidiniai ir kad bibliotekose taikomi duomeny standartai ${ }^{30}$ ir jose naudojamos informacinès sistemos buvo sukurtos ir optimaliai pritaikytos tradiciniams biblioteku dokumentams. Tačiau tèra labai nedaug biblioteku, kuriose nebūtų saugomi bent jau negausūs meno ar kultūros objektai. Tai gali būti: ¡̇kūrèjų ar dovanotojų portretai; dekoratyvinę funkcija atliekantys meno kūriniai; meno ir kultūros objektai, patekę i biblioteką kartu su kieno nors dokumentais arba kokiu nors būdu susiję su bibliotekos tekstiniajs fondais. Daugeliu panašiı̨ atvejų objektų skaičius nėra pakankamas, kad pasiteisintų atskiros duomenų bazès 
kūrimui būtinos lëšos, Kita vertus, atskiros duomenų bazès buvimas sunkina fondı vadybos veikla, pavyzdžiui, inventorinimą ir apytaka, kliudo teikti integralią prieiga prie viso rinkinio bei įrašus apie objektus i stambesnes biblioteku metaduomenı sankaupas, tokias kaip OCLC WorldCat $t^{31}$.

Veiksmingiausias būdas bibliotekos viduje tvarkyti objektus ir teikti prie ju prieigq - ju dokumentavimas OPAC. Nebūtina rengti labai išsamius irašus; aprašas gali būti minimalus, nes bibliotekos personalas tikriausiai nebus pakankamai kvalifikuotas, kad sugebėtu ji papildyti ar pataisyti taip, kad meno istorikai pripažintu ji tinkamu. Net trumpas aprašas, susietas, jei imanoma, su objekto vaizdu, suteiktų pagrindinius identifikuojančius duomenis, kurie, išplatinti per OPAC, gali paskatinti vartotojus teikti papildomą informacija. Bibliotekininkaj, kuriems prieinama išsamesnè dokumentacija arba kurie turi galimybę perimti meno istoriku, saugotoju, prekybos agentц ar kolekcionieriu patirtị, gali parengti išsamesnius aprašus. Kad ir kokia būtu įrašo apimtis, bibliotekininkams $\mathrm{CCO}$ bus nepamainomas vadovas atrenkant ir išreiškiant informacija tinkamą meno ir kultūros kūriniams aprašyti.

Toliau aptariamos pagrindinés problemos, su kuriomis susidurta méginant taikyti CCO Morgan bibliotekos ir muziejaus (Niujorkas, JAV) meno ir kultūros kūriniụ katalogavimui. Morgan bibliotekos ir muziejaus rinkiniai sudaryti daugiausia iš spausdintinių knygu, periodikos, rankraščių ir natų, tačiau juose yra ir svarbių kolekciju, sudarytụ iš meno ir kultūros kūriniu, tokił̨ kaip piešiniai, atspaudai, cilindriniai antspaudai is Artimuju Rytu, paveikslai, skulptūros, dekoratyviniai objektai ir artefaktai, pasižymintys nepaprasta ivairove: nuo Voltaire portfelio iki John Ruskin švininių kareivèlių ir John Keats plauku sruogos. Morgan bibliotekos ir muziejaus sprendimas ¿̇sigyti Voyager bibliotekinę sistemą ir teikti prieiga prie visos medžiagos per šios sistemos OPAC sutapo su Vaizdo ištekliu asociacijos nutarimu rengti $\mathrm{CCO}$ gaires. Keletas šios institucijos bibliotekininkų turējo galimybę dalyvauti šị gairị redaktoriu tarybos veikloje ir taikyti ši naujai rengiamą standartą aprašant savo kolekcijas.

Nors imanoma rengti „grynus" $\mathrm{CCO}$ ịašus MARC formatu, tai nèra labai naudinga. Stilistiniai skirtumai tarp AACR ir CCO (pvz., CCO nevartojama ISBD skyryba) gali būti đrastiški, o skirtingi duomenų elementụ analizei naudojami būdai kelia atskleidimo, indeksavimo ir paieškos problemu. Bibliotekos kontekste CCO geriausia taikyti kaip bibliotekų katalogavimo standartų priedą ir taip išskirti tas objektų savybes, kurių neapima tekstiniams kūriniams ir publikuotiems dokumentams skirtos taisyklès.

Objekto arba kūrinio rūšis yra vienintelè svarbiausia informacija apie objektą; kaip teigiama $\mathrm{CCO}$, „kūrinio rūšis yra loginis katalogo irašo akcentas " ${ }^{32}$. Biblioteku atliekamame katalogavime objekto rūšis laikoma laikmenos informacija ir priešinama turinio informacijai; ji labiau apibūdina konkrečios kūrinio apraiškos pristatymo būda o ne esminę kūrinio savybę. Dažniausiai bibliotekų fonduose pasitaikanti objekto rūšis bibliografiniame ịraše niekur neatsispindi, nes laikomasi nuomonès, kad, jei nenurodyta kitaip, aprašomas vienetas yra knyga. Neknyginei medžiagai priklausančio objekto rūšis irašoma ivairiuose fiksuotuose ir kintamuose MARC jrašo laukuose, kuriu nè vienas neatitinka objekto katalogavimui keliamu reikalavimu.

MARC formato 300 lauko polaukis \$a (apimtis), kuris yra fizinio aprašo srities dalis, neatsispindi pirminèse paieškos rezultatụ aibèse ir nepanašu, kad jis būtų indeksuojamas daugelio bibliotekiniu sistemц, nes yra daugiausia skirtas paginacijai irašyti. MARC formato 245 lauko polaukis $\$$ h (priemonè), vartojamas jrašyti bendrą medžiagos apibūdinimą, labiau skirtas atvaizdavimui ir indeksavimui, tačiau vieninteliai objektui taikomi terminai, kuriuos AACR nurodo vartoti bendrame medžiagos apibūdinime, yra graphic, art original ir realia, jie visi pernelyg bendro pobūdžio ir todèl nèra naudingi. Morgan bibliotekininkai objekto rūšiai irašyti pasirinko 245 lauko polauki \$h, tačiau minètus AACR terminus pakeitẻ labiau tinkančiais. Tokie specifiniai objekto rūši nusakantys terminai, kaip drawing, painting ar sculpture, vartojami objektams, kurių antraštès atspindi, ką kūrinys vaizduoja, kaip šios XIX a. Italijos menininko Pelagio Palagi scenos kompozicijos atveju:

\section{0 \$a Interior of a Vast Roman Fortress \$h [drawing]}

Objektams, kuriems nebūdingas vaizdinis turinys ir kurių antraštè nusako objekto rūši, vartojamas bendresnio pobūdžio terminas „objektas“:

24510 \$a Embroidered 18th-Century Italian Waistcoat Made for Count Gasparo Gozzi \$h [object]

(Atkreipkite dèmesí, kad antraštè apima asmens, kuriam buvo pagamintas rūbas, vardą. Daugelio kultūros objektu reikšmę ir vertę nulemia jų sq̨saja su ižymiais asmenimis, o ne jų, kaip artefaktų, vertè. Šio santykio atspindējimas antraštèje padaro objektus labiau prieinamus vartotojams.)

Kad būtų optimizuojama paieška ir sudaryti naršymui skirti sąrašai, kūrinio rūšiai nusakyti vartojami žanrą apibūdinantys (MARC formato 655 laukas) terminai (iš Art and Architecture Thesaumu S $^{33}$ ), kurie dar praplečiami nacionalinès kultūros ir laikotarpio apibūdinimais:

655 7 \$a Drawings \$x Italian \$y 18th century. \$2 aat 655 7 \$a Drawings \$x Italian \$y 19th century. \$2aat

Biblioteku katalogavimo taisyklès skirtos publikuotiems dokumentams aprašytí. Jos parengtos turint galvoje 
dokumentus, kurie patenka i biblioteką su antraštiniame lape jau pateiktu formaliu aprašu; informacija, kurios nẻra nustatytuose duomenu šaltiniuose, pateikiama laužtiniuose skliaustuose. Nepublikuoti objektai neturi antraštinių lapц, todèl aprašo dalis turi būti pateikiama remiantis ivairiais šaltiniais ir paties kataloguotojo nuovoka. Kadangi toks duomenu pateikimas laikomas iprastu dalyku, laužtiniai skliaustai nevartojami ${ }^{34}$. Dar labiau kataloguotojus stebina tai, kad pačiame objekte esanti informacija, pavyzdžiui, ịrašai ar ženklai, nelaikoma svarbesne už informacija, esančią kituose šaltiniuose. CCO atspindi meno katalogavimo praktika, kai pirmenybė teikiama sudarytai antraštei, išsamiai nusakančiai objekto vaizdini turinị ar funkcija, o ne pačiame objekte esančiai aprašomajai informacijai, net jei ji ịamžinta paties menininko ranka. Taip pat rekomenduojama ̨̣rašyti antraščił variantus ir ankstesnes antraštes, atidžiai perrašyti visus ịrašus ir ženklus. Pateiksime pavyzdi, kaip šios rekomendacijos atsispindi mūsu katalogo MARC iraše:

1001 \$a Zuccari, Federico, \$d 1542 or 3-1609.

24510 \$a Allegory of Sin \$h [drawing]

24633 \$a Pianto, Peccato, Spavento \$h [drawing]

24633 Sa Allegoria del Peccato \$h [drawing]

562 \$a Inscribed in black chalk, by the artist, "PIANTO / PECAT[O] / SPAVENTO"; at lower edge at center, in pen and brown ink, "Zuccaro"; on mount, in lower left corner, in pen and brown ink, "Zuccaro"; on verso of mount, in pen and brown ink, "Pa Auctionkost P. 1-9".

Vartotojams suteikiama visapusiška nauda: pateikiama prasminga antrašté katalogo kalba, taip pat prieiga prie visos objekte užrašytos informacijos, galinčios padèti nustatyti, kam objektas priskirtinas, ar jo proveniencija. Atkreipiame dèmesį $\mathfrak{i}$ tai, kad šiame pavyzdyje su menininku susije duomenys jrašyti MARC formato 562 lauke (egzemplioriaus ir versijos identifikavimo pastaba), o ne 245 lauko polaukyje Sc (atsakomybès duomenys). Informacijos apie kūrèja, unikaliame objekte užrašytos asmens, kuris galèjo būti (arba galẻjo nebūti) objektą sukūręs menininkas, reikšmė nèra prilyginama formaliu spausdintinjame antraštiniame puslapyje pateikiamu duomenų reikšmei.

CCO autoriai pasirinko išmintingą sprendimą neišradinèti dviračio ir nekurti vardų ivedinių sudarymo taisyklių. Kataloguotojai gali patys pasirinkti vardų autoritetiniu duomenu šaltinius ir bibliotekininkams nereikia nerimauti dèl OPAC galinčiŁ iškilti prieštaravimy tarp kreipties elementu, suteikiančių prieiga prie ju objekıı, ir kreipties elementu, suteikiančiu prieig̨ prie antrinės medžiagos. Vis délto CCO nukrypsta nuo AACR, kai traktuojamas kolektyvų, giminių ir nežinomų dailininkų kūrybinis vaidmuo. Skirtingai negu AACR, CCO kolektyvams, tokiems kajp Worcester Royal Porcelain Company ar Tiffany and $C o$., priskiriama pagrindinè atsakomybẻ už ju dirbtuvèse ar cechuose pagamintus objektus; giminès, tokjos kaip Italijos menininku ir teatro dailininku Bibiena giminè, laikomos pagrindiniais meno ir kultūros kūrinį̣, priskiriamų šiai XVII-XVIII a. gyvenusiai šcimai, kūrẻjais $^{35}$. Morgan bibliotekos ir muziejaus meno ir kultūros kūriniu irašai atitinka CCO nuostatą laikyti kolektyvų ir giminiџ vardus šių kolektyvı arba giminjų sukurtı̨ ar pagamintų objektı pagrindiniais jedediniais.

Bibliotekininkams ne taip lengva pritarti nuostatai, kad anoniminiams kūrẻjams būtini ịvediniai. Kai tekstinio kūrinio autorystè neaiški ar nežinoma, biblioteky kataloguotojai jraše praleidžia autoriaus lauką, o esminio kreipties elemento funkciją suteikia antraštei. Tačiau kataloguojant tekstinius kūrinjus tai pasitaiko ne taip dažnai; meno kūrinių, kuriụ autorystès nęmanoma priskirti žinomam menininkui ar netgi menininkui, identifikuojamam kokia nors charakteringa fraze, pavyzdžiui, Achilles Painter, yra tick daug, kad meno kataloguotojai yra sukūrę daugybę būdų, kaip vartolojams patcikti informacijos apie kūrinio sukūrimo kontekstą:

Attributed to Francesco Salviati.

Formerly attributed to Francesco Salviati.

Wotkshop Francesco Salviati.

Follower of Francesco Salviati.

After Francesco Salviati.

Italian, 16th century.

Tokiais atributais grindžiami kreipties elementai gali būti stebétinai lengvai integruojami ¡ OPAC paieškos parinktis. Morgan bibliotekos ir muziejaus kataloge Salviati AACR vardo forma, kuri vartojama indeksuojant meno kūrinius, neabejotinai priskirtinus Salviati, ir Salviati kūriniams atstovaujančią antrinç medžiaga, patcikiama paieškos parinkčiụ sąrašo pradžioje, po to seka ne pagal AACR sudaryti kreipties elementai kartu su patikslinimais:

Salviati, Francesco, 1510-1563.

Salviati, Francesco, 1510-1563, after.

Salviati, Francesco, 1510-1563, attributed to.

Salviati, Francesco, 1510-1563, formerly attributed to.

Salviati, Francesco, 1510-1563, workshop of.

Taip pat vartojami kreipties elementai nacionaliniu kultūrụ pavadinimams (nors Morgan biblioteka ir muziejus teikia pirmenybę terminui ,anoniminis“, o ne CCO rekomenduojamam ,nežinomas“): 
Anonymous, Italian, 16th century.

Bibliotekų katalogavimo taisyklès fiziniam aprašui yra ribotos; jose pirmiausia akcentuojama vieneto apimtis (t. y. puslapiu, lapu, tomu, mikrokortų, ričiu ir t. t. skaičius), iliustraciju buvimas ir matmenys (knygu pateikiamas tik aukštis). Kadangi kiekvienas meno kūrinys yra unikalus fizinis objektas, identifikavimo tikslais būtinas tikslesnis ir išsamesnis aprašas. Šią užduotị komplikuoja tai, kad egzistuoja praktiškai neribotas skaičius skirtingų objektuł; grafikos kūrinius ipratęs aprašinèti kataloguotojas gali susidurti su neiveikiamais sunkumais, pabandęs kataloguoti monetą ar sienini laikrodi. Su objektu aprašais besikamuojantiems bibliotekininkams gelbẻjimosi ratas gali būti CCO „Fizinių charakteristikц“ (Physical Characteristics) skyrius. Śiame skyriuje, kurio apimtis du kartus didesnè negu bet kurio kito duomenu elementams skirto skyriaus, suteikiama patarimų, kaip turi būti užrašomi daugybẻs skirtingų rūšiu objektų matmenų, medžiagos ir atlikimo technikos, laidu ir korektūrinių atspaudu, irašu ir ženklụ bei fizinès būklès duomenys. Matmenu skyrius ypač naudingas nespecialistams, kuriems gali neateiti i galva itraukti duomenis apie formą (ovalios miniatiūros), svori (raižyto brangakmenio ar megalitinio akmens) ar dydi (apdaro).

Tiek MARC, tjek AACR, ypač AACR grindžjamos taisyklès, skirtos specialiu fondu katalogavimui, numato išsamesnio fizinio aprašo galimybę, todèl be didesniu sunkumu imanoma pagal $\mathrm{CCO}$ parengtus ftzinius aprašus itraukti i OPAC irašus. MARC formato 340 laukas (fizine priemoné) skirtas ,fizinio aprašo informacijai apie vieneta, kuriam naudoti būtina techninė iranga arba kurio konservavimui ar saugojimui keliami ypatingi reikalavimai" laukas labiau struktūruotas negu $\mathbf{3 0 0}$ laukas (fizinis aprašas), todèl yra galimybė priemonę ir laikmeną ịrašyti i atskirus polaukius. Pateiksime pavyzdi, kaip 340 laukas naudojamas XVI a. skulptūrai aprašyti:

340 \$b Sculpture - height: $123 / 4$ in. (315 mm), width: $113 / 8$ in. $(290 \mathrm{~mm})$, depth: $6 \mathrm{l} / 2 \mathrm{in.}(165 \mathrm{~mm})$; Base height: $31 / 2$ in. $(90 \mathrm{~mm})$, width: $14 \mathrm{l} / 4$ in. $(363 \mathrm{~mm})$; depth: 9 in. $(227 \mathrm{~mm})$ \$c Terra cotta with polychrome decoration.

Visi žiniatinklio ištekliai žiūrèti 2009 m. gegužẻs 15 d.

' RDA: Resource Description and Access. American Library Association, Canadian Library Association, and the Chartered Institute of Library and Information Professionals. http:// www.rdaonline.ory/
Kitas pavyzdys iliustruoja daug paprastesni XIX a. medaliono, pagaminto iš Venecijos kristalo, aprašą:

$340 \_$\$b 7 x $4 \mathrm{~cm} \mathrm{\$ c} \mathrm{Crystal} \mathrm{and} \mathrm{silver.}$

Apibendrinant būtų galima pasakyti, kad ir nedidelès apimties informacija turi nueiti ilgą kelia, kad galètı pasitarnauti prieigai prie biblioteku rinkiniuose esančiu objektų. CCO, taikomas kartu su bibliotekų duomenu standartais, gali būti labai svarbus ịrankis, padedantis bibliotekininkams rengti meno ir kultūros kūriniụ irašus, kurie darniai egzistuotų greta įrašų, sudarytų bibliotekose vyraujantiems fondams. Antra vertus, integruojant vaizdų rinkinius (pvz., meninès fotografijos archyvus) i biblioteku fondus ir galiausiai LAM terpe, vis grésmingesni mastą igyja vaizdų MARC kontekste problema. Vaizdo ištekliu kataloguotojams paprastai kyla problemu dẻl to, ar objektı̨ grupę kataloguoti kaip serijø, komplekta, ar kaip atskirus objektus, ir kaip struktūruoti objekto / vaizdo santykị. Bibliotekininkai yra sukaupę darbo su daug kūrinį̣ apimančiomis serijomis, atskirais periodikos numeriais ar neišsamiais jos komplektais ir archyvų fondais patirti. $\mathrm{CCO}$ gali pasitarnauti kaip priemonè, padedanti abiem šioms bendruomenèms spręsti objektų ir vaizdų srityje iškylančias problemas.

\section{Išvada}

Keletas paskutinjujjų dešimtmečiu pasiżymëjo intensyvia kultūros kūriniams aprašyti skirtų duomenu standartụ plètra, kurios rezultatas - skirtingus požiūrius vientjančio teorinio pagrindo sukūrimas. Śiai veiklai bendrą pamatą suteikia katalogavimo vadovas Cataloguing Cultural Objects, kurio plètrą skatina spartus technologiju vystymasis ir kultūros îstaigu šviečiamoji misija - teikti prieigą prie informacijos apie meno kūrinius. Šiandien, muzieju, biblioteku specialiuju kolekciju ir vaizdu rinkiniu sankirtos sąlygomis, informacijos apie kultūros kūrinius katalogavimui ir dalijimuisi ja taikomas $\mathrm{CCO}$, kuriame pateikiami išsamūs aprašomuju metaduomenų elementụ rinkiniai ir specializuoti kontroliuojami žodynai.

\section{Iš anglu kalbos vertè T. Auškalnis}

Straipsnis parengtas pagal pranešimą, skaitytą $2009 \mathrm{~m}$. Milane (Italija) vykusioje 75-ojoje IFLA konferencijoje.

2 Baca, M.; Harpring, P.; Lanzi, E.; McRae, L.; Whiteside, A., eds. Calaloging Cultural Objects: A Guide to Describing Cultural Works and Their Images. American Library Association: Chicago, 2006.

${ }^{3}$ VRA Core Calegories 4,0, Visual Resources Association. http:// www.vraweb.org/resources/datastandards/intro.htm!

4 Categories for the Description of Works of Arl (CDWA). J. Paul Getty Trust, College Art Association. http:/www.getty.edu/ ressearch/conducting_rescarch/standards/cdwa/ 
${ }^{3}$ Dublin Core Metadata Initiative. http://dublincore.org/; Metadata Object Description Schema (MODS). Library of Congress. http://www.loc.gov/standards/mods//; MARC2I Formars. Library of Congress. http://www.loc,gov/marc/

- California Digital Libraries, Shared Metadata Working Group, Metadata Submission Guidelines for UC Shared Images. 26 March 2009. http://www.cdlib.org/inside/projects/image/ msg_ucsi.pdf

${ }^{7}$ ARTstor Images for Education and Scholarship. http://www. artstor.org/index.shtml

"NISO, A Framework of Guidance for Building Good Diginal Collections 16 April 2008. http://framework.niso,org/node/5

"Trendafitova, Malina. "Development Environment for Building Common Catalogue for Representation of the Culture-Historical Heritage of Bulgaria." Bulgarian Academy of Sciences Cybernetics and Information Technologies. Vol. 7, no. I (2007), 95-105. http://74.125.95.132 search?q=cache: $16 \mathrm{UMdXEgH2AJ:}$ www.cit.iit.bas.bg/CIT 07/v7-1/95-105.pdf+Electronict Catalogue +of + Bulgarian + Cultural + Historical + Heritage\& $\mathrm{cd}=$ $2 \&$ hl $=$ en\& $c t=c l n k \& g l=u s \& c l i e n t=f i r e f o x-a$

${ }^{10}$ Cilès valstybiniams muziejams skirta dokumentavimo sistema, SUR ${ }^{\mathrm{TM}}$, grindžiama CDWA, o muzieju specialistams skirtas vadovas parengtas $\mathrm{CCO}$ modelio pagrindu. Nagel, Lina, ed. Manual de registro y documentación de bienes culturales. Santiago de Chile: Andros Impresores, 2008.

"State Museums of Berlin, Institute for Museum Research / Staatiche Museen zu Berlin, Institut für Museumsforschung. http://www.smb.museum $/ \mathrm{ifm} / \mathrm{index}+\mathrm{php}$ ? ls=12\&topic= Home\&lang-en\&te -ja\&tf-ja

12 "FRBR and Works of Art, Architecture, and Material Culture," by Murtha Baca and Sherman Clarke, in Atlene Taylor, Understanding FRBR: What It Is and How It Will Affect Ow Retrieval Tools (Westport, Connecticut and London: Librarics Unlimited, 2007).

${ }^{13}$ Museum Data Exchange Project. OCLC/RLG Programs. hitp:/ www.oclc.org/programs/ourwork/collectivecoll/sharecoll/ muscumdata.htm

${ }^{14}$ Waibel, Günter. "Museum Date Exchange: Asking the right questions “ 20 March 2009, OCLC/RLG Programs, Hanging Together blog, http://hangingtogether.org/? $\mathrm{p}=644$

${ }^{15}$ CDWA Litc. http://www.getty.edu/research/conducting_rescarch/ standards/cdwa/cdwalite.html

It Open Archives Initiatives Protocol for Metadata Harvesting. http://www.openarchives.org/pmh/

${ }^{17}$ CDWA Lite Specification: A list of Elements, Tags, Description, and Examples, p. 4-5. http://www.getty.edu/research/conducting research/standards/cdwa/cdwalite.pdf

${ }^{18}$ OAICatMuseum 1.0. http://www.oclc.org/research/software/oai/ on icatmuseum.htm

${ }^{14}$ COBOAT metadata publishing tool, http://www.oclc.org/research/ soffware/coboat/default.htm
${ }^{20}$ ARTstor Images for Education and Scholarship, Personal Collecfion Guidelines. http:/help.artstor.org/wiki/index.php/Personal Collections

${ }^{21}$ Museum Computer Network, Taiwan Chapter. MuseFusion. hitp://mcntw-stds.teldap.tw:8080/musefusion/

${ }^{22}$ CIDOC Conceptual Reference Model, http://cidoc.ics.forth.gr/

${ }^{23}$ museumdat. http://www.museumdat.org/index.php? $1 \mathrm{n}=\mathrm{en} \& \mathrm{t}=$ home

${ }^{24}$ BAM: Portal zu Bibliotheken Archiven und Museen (BAM). http://www.bam-portal.de/

${ }^{25}$ DigiCULT Museen Schleswig-Hostein. http://www.digicult-sh,de/ Bildarchiv Foto Marburg. http://www. fotomarburg.de/ EDL Foundation, Europeana. http://www.europeana.eu/portal/

${ }^{26}$ Socicty of Architectural Historians Architecture Resources Archive (SAHARA), http://www.sah.org/index.php?ste=gendocs\&ref= HOME\& category=Sahara\%20HOME

" University of Virginia Library, Scholarly Communication Institute SCI 4 Anchitectural History 2006. hitp://www.uvasci.org/archive/ architectural-history-2006/

2" The Getty Research Institute. Union List of Artist Names Online (ULAN). http://www.getty.edu/research/conducting_research/ vocabularies/ulan/

29 The Getty Research Institute, Cultural Objects Name Authority" (CONA). http://www.getty,edu/research/conducting_research/ vocabularies/contribute.htmlizcona

${ }^{30}$ Morgan biblioteka ir muziejus, kaip ir beveik visos Amerikos bibliotekos, kaip duomenu turinio standartą taiko AACR ir MARC2I kaip duomenu formati ir komunikacijos standarta. Istaigos, kurios taiko kitus bibliotekoms skirtus duomenu standartus, bandydamos objektu aprašus integruoti i savo katalogus, gali susidurti su skirtingomis problemomis. Vienam iš šio straipsnio autorių, O'Keefe, būtų labai idomu sužinnoti apic tokiu biblioteku patirti.

" OCLC Online Computer Library Center, Inc. WorldCal. http://www. worldcat.org/

${ }^{32}$ Cataloging Cultural Objects, p. 48.

${ }^{33}$ The Getty Research Institute. Arf \& Architecture Thesaurus Online. (AAT), http://www.getty.edu/research/conducting_research/ vocabularies/aat/

${ }^{3+}$ Tai, kad RDA: Resoure Description and Access - katalogavimo taisykles, kurios turètu pakeisti AACR - nenurodo vartoti laužtinių skliaustų aprašant dokumentus be fonnalaus antrǎ̌tinio lapo, gali reikšti, kad skirtingos metaduomenų kūrèjụ bendruomenès pradeda viena iš kitos mokytis.

${ }^{35}$ RDA, kuriame atsispindi archyvinio katalogavimo patirtis, bus laikomasi nuostatos, kad giminems gali būti priskiriama autorystè.

${ }^{36}$ MARC 21 Format for Bibliographic Data. 1999 Edition. http:// www.loc.gov/marc/bibliographic/bd340.htm! 